\title{
Caddoan Reburial
}

Thomas E. Speir

Unknown

Follow this and additional works at: https://scholarworks.sfasu.edu/ita

Part of the American Material Culture Commons, Archaeological Anthropology Commons, Environmental Studies Commons, Other American Studies Commons, Other Arts and Humanities Commons, Other History of Art, Architecture, and Archaeology Commons, and the United States History Commons

Tell us how this article helped you.

This Article is brought to you for free and open access by the Center for Regional Heritage Research at SFA ScholarWorks. It has been accepted for inclusion in Index of Texas Archaeology: Open Access Gray Literature from the Lone Star State by an authorized editor of SFA ScholarWorks. For more information, please contact cdsscholarworks@sfasu.edu. 


\section{Caddoan Reburial}

\section{Creative Commons License}

(c) (i) (8)

This work is licensed under a Creative Commons Attribution-NonCommercial 4.0 International License 


\section{CADDOAN REBURIAL}

\section{by Thomas E. Speir \\ Northeast Texas Archeological Society}

\begin{abstract}
On February 7, 1993 in eastern Texas, the remains of a prehistoric Caddoan Indian were reburied in the original grave. A small ceremony was held to mark the occasion. Representatives of the Caddo Tribe from Oklahoma and Louisiana were in attendance, as were members of the Northeast Texas Archeological Society (NETAS). This report deals with one case of recently excavated human remains.
\end{abstract}

\section{Background}

The burial was one of two discovered during NETAS's 1992 Field School excavations at 41 HS524, a predominantly Caddoan I and II farm site. The site was located in Harrison County, within the Sabine River drainage basin of Texas. The archeologist in charge of the field school, Dr. John Keller, directed the removal of one burial's cranial area within a block of soil matrix during the field school. The removed cranial matrix block was carefully transferred in special packing to a lab area where it was cleaned.

The burial was estimated to be approximately 1000 years old. The few existing remains revealed little more than the height of the individual, between 5' $2^{\prime \prime}$ and 5' 4". After cleaning, all that remained of the cranial area were some teeth and a few bone fragments. These were transferred to Harrison County Coroner, Dr. Robert Palmer, for a pathology analysis. His study showed that the individual was under 20 years of age at death. Both Dr. Keller and NETAS felt that prompt reburial of the remains was the most appropriate course.

\section{Discussion}

There is no single policy that deals with every reburial case. Human remains from prehistoric burials are frequently brought to the attention of the archeological community, some unearthed by accident and others by intent. Disposition of these remains is a problem that is increasingly being addressed by various organizations (Texas Archeological Society Board of Directors 1993).
There are occasions when reburial of human remains, after appropriate scientific study has confirmed that such remains have no further legitimate use for scientific or educational purposes, is a responsible course of action. Further, reburials do seem to promote better relations with concemed Native Americans and other cultural and religious groups. Reburials provide these groups with the evidence that discussions with the archeological community on the subject of reburials do not end with "another white man's treaty", as a television news commentator said.

In some instances, burials must be exhumed to prevent their destruction from new construction. Stewards for the Office of the State Archeologist are advised to become involved in the excavation of human remains only when a burial is in imminent danger of destruction (Cloud 1993:12).

Each case must be evaluated on an individual basis. Although reburial is primarily a legal and political issue, on those occasions when reburial of remains can be considered a scientifically responsible act, consideration should be given this course of action. This can be justified by the benefit such an act could represent to the archeological community, not only in better relations with Native Americans, but through closing ranks with them against looters (Mallouf 1993:1).

Reassuring concerned parties that proper care and respect are always shown for human remains when they are in the hands of qualified professionals does not always eliminate their objections to scrutiny of the remains. Reburials, when feasible, provide support for the argument that proper care and respect by professionals for human remains extends beyond the laboratory. This position may go a long way toward eliminating citicism by Native American groups.

In this particular case, full examination of the remains by qualified professionals, including the principal investigator and a pathologist, yielded all information possible. Retaining the few teeth and bone fragments in a repository would have taken up much needed storage space. By offering to sponsor the reburial, NETAS displayed the willingness of people in the archeological community to work with Native Americans in honoring their goals and interests whenever possible.

The burial ceremony was conducted by Mr. Lymon Kiomute of Lookeba, Oklahoma. Mr. Kiomute was assisted by Rufus "Chief" Davis from Houston, Texas, of the Louisiana Caddo Addais. Several other members 
of the Caddo Addais attended the ceremony, including Ms. Pat Wray of Kilgore, Texas. The date of the reburial was set in conjunction with the East Texas Archeological Conference which was held in Tyler on February 6th. Mr. Clark and Mr. Kiomute got the opportunity to hear first-hand some of the current projects being pursued by archeologists in East Texas in their efforts to learn more about prehistoric Caddoan culture. To help offset travel expenses for the Oklahoma Caddo representatives, NETAS "passed the hat" to finance the trip. Clark and Kiomute stayed at the home of NETAS founder Thomas Speir at his horse farm north of Marshall.

Goodwill and hopes for more occasions to work together toward the rediscovery of prehistoric Caddoan cultures were expressed by all parties. Although NETAS concurs that indiscriminate reburials are not scientifically responsible or culturally beneficial, this view does not eliminate reburial when the benfits reaped outweight loss of potential information.

\section{REFERENCES}

Cloud, Andy

1993 The Texas Archeological Stewardship Network and the Human Remains Issue. Texas Archeological Stewardship Network Newsletter 8(1): XX.

\section{Mallouf, Bob}

1993 The Human Remains Issue: Archeology Under the Gun. Texas Archeological Stewardship Network Newsletter 8(1):XX.

\section{Texas Archeological Society Board of Directors}

1993 Texas Archeological Society Human Remains Policy Statement. Texas Archeological Society Newsletter 37(2): 15 .

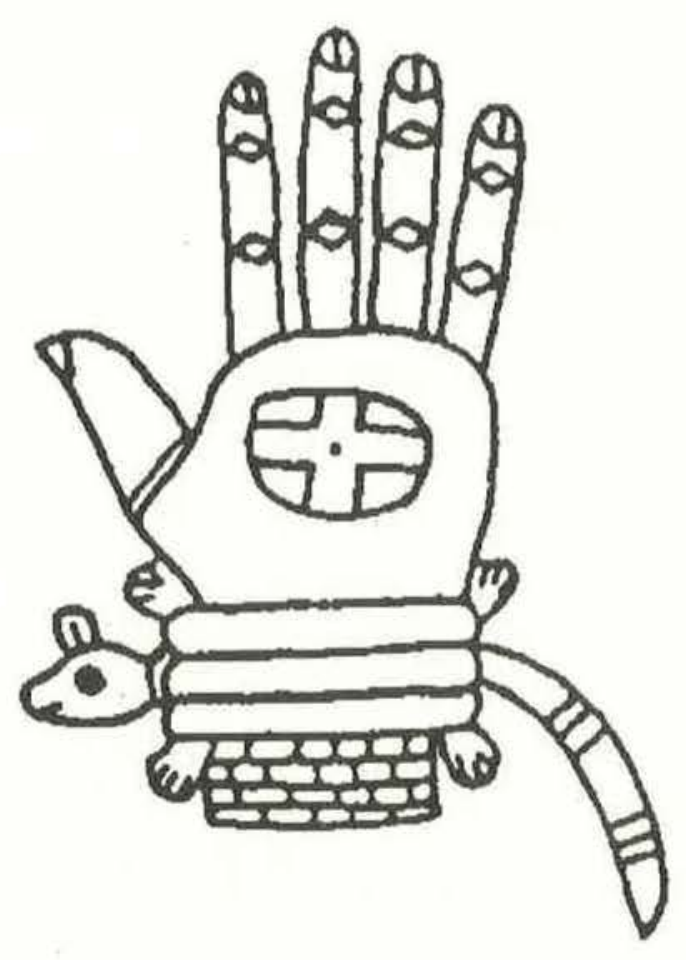

